\title{
Effects of the Dwarfing Gene from Dee-geo-woo-gen and Three Others on High Temperature Tolerance at Flowering
}

\author{
Masayuki Murai ${ }^{1}$, Shohei HIRose, Noriyuki Suzuki ${ }^{1)}$, \\ Masakatsu Yamane ${ }^{2)}$ and Shigetoshi $\mathrm{SATO}^{3)}$ \\ 1) College of Agriculture and Veterinary Medicine, Nihon University, \\ Setagaya-ku, Tokyo 154 \\ 2) Arid Land Research Center, Tottori Univeristy, Tottori 680 \\ 3) College of Agriculture, University of the Ryukyus, Nishihara, Okina- \\ wa 903-01
}

The effects of four dwarfing genes on the high temperature tolerance at flowering were investigated. The genes were $d-47(\mathrm{t})$ (dee-geo-woo-gen dwarf), $d-12$ (yukara dwarf), $d-18^{k}$ (kotaketamanishiki dwarf), and $d-35(\mathrm{t})$ (tanginbozu dwarf). The following lines were used: the isogenic lines of Shiokari, i.e., $d-47$ line, $d-12$ line, $d-18^{k}$ line and $d-35$ line, and the isogenic line of $d-47(\mathrm{t})$ of Taichung 65 , i.e., $d-47(\mathrm{~T} 65)$ line. At $35^{\circ} \mathrm{C}, d-47$ line and $d-18^{k}$ line followed by $d-12$ line showed higher spikelet fertilities but $d-35$ line showed a lower spikelet fertility than Shiokari. At $37^{\circ} \mathrm{C}, d-47$ (T65) line had some fertile spikelets $(8.8 \%)$, although Taichung 65 had almost no fertile spikelet. It is recognized that $d-47(\mathrm{t})$ enhanced the high temperature tolerance under the two genetic backgrounds with different tolerances. The following trend was shown: the more the germinated pollen grains per spikelet, the higher the spikelet fertility.

KEY WORDS: Oryza sativa L., dwarf, high temperature tolerance, sterility, pollen

\section{Introduction}

In rice, the high temperature damage at flowering is the most serious through all growth stages (NishiYAma and SATAKe 1981). There are several reports on occurrences of the high temperature damage at flowering in rice: on cultivations in deserts of Iraq (ITo 1964), Egypt (Sato 1982) and Sudan (Mastushima et al. 1982), and on the dry season crop in the Central Plain of Thailand (OsADA et al. 1973). The latter was due to the high temperature during April and May, i.e., the last two months of the dry season. At the most of the meteorological observatories in Southeast Asia except Indonesia, April or May is the month of the highest temperature in the year (Japan Meteorological Agency 1990). Hence, the dry season crop involves the risk of suffering the high temperature damage. According to NishiYama and Satake (1981), the gross area in which such damage occured was estimated to be 4,000,000 ha, and it was foreseen that this would expand with the increase of double and triple croppings. Short culm, photoperiod insensitive and early maturing cultivars, e.g., several of the IR-number cultivars, are used for the dry season crop in many cases. Most of them inherit the dwarfing gene which originates from Dee-geo-woo-gen. It was tentatively designated as $d-47(\mathrm{t})$ (Kinoshita and Shinbashi 1982, and Futsuhara et al. 1986). In this study, the authors investigated whether $d-47(\mathrm{t})$ and three other dwarfing genes affect the high temperature tolerance at flowring or not, by using isogenic lines.

Received May 28, 1991.

Accepted November 8, 1991. 


\section{Material and Methods}

\section{Experiments by isogenic lines of Shiokari}

The names of the dwarfing genes in this study and their gene symbols follow the proposal by the Committee on Gene Symbolization, Nomenclature and Linkage Groups (Futsuhara et al. 1986).

Shiokari, and its isogenic lines of $d-47(\mathrm{t})$ (dee-geo-woo-gen dwarf), $d-12$ (yukara dwarf), $d-18^{k}$ (kotaketamanishiki dwarf) and $d-35(\mathrm{t})$ (tanginbozu dwarf) were used. They were abbreviated to $d-47$ line, $d-12$ line, $d-18^{k}$ line and $d-35$ line with their gene symbols. The number of backcrosses was 7 in 1984 and 8 in 1985 for both of $d-47$ line and $d-12$ line, 11 in 1984 and 12 in 1985 for $d-18^{k}$ line, and 10 for $d$-35 line. The recurrent parent, Shiokari is of intermediate culm length and one of the leading varieties of Hokkaido around 1970 (Hokkaido Central Agricultural Experiment Station 1979). The traits of the four dwarf lines in morphological and floral characters were reported in detail by MuRAI et al. (1982), Murai and Kinoshita (1983), Murai et al. (1990), and Murai et al. (1991). According to Murai et al. (1990), $d-12$ is the same as or allelic ot the dwarfing gene of Fukei 71 which is resistant to lodging (Futsuhara 1968). $d-18^{k}$ seems to somewhat enhance the cool temprature tolerance at the booting stage (MURAi et al. 1991). Tanginbozu (or Ginbozumidashi), the gene source of $d-35(\mathrm{t})$, recorded a high yield $(857.5 \mathrm{~kg} / 10 \mathrm{a})$ in 1951 (UchiYAMADA 1981), but it and its derivatieves were not widely cultivated (OKADA et al. 1967).

The experiemnt in 1984 was conducted in the Arid Land Research Center, Tottori University. Shiokari and its isogenic lines except $d-35$ line were grown in a vinyl house from April to June. Six seedlings were separately transplanted to a $1 / 5,000$ a cylindrical pot in a circle. The total of fertilizers applied per pot corresponded to $0.42,0.27$ and $0.30 \mathrm{~g}$ for $\mathrm{N}$, $\mathrm{P}_{2} \mathrm{O}_{5}$ and $\mathrm{K}_{2} \mathrm{O}$, respectively. High temperature treatments were conducted in artificial light growth rooms which were illuminated at about $27,000 \mathrm{~lx}$ from 6 a.m. to 7 p.m. Different temperatures, viz. 26,35 and $38^{\circ} \mathrm{C}$ were set from 9 a.m. to 6 p.m.; the relative humidity was kept at about $70 \%$ during the nine hours. At night (7 p.m. to 6 a.m.), the temperature was set at $20^{\circ} \mathrm{C}$ for all the rooms of the treatments. The length of each treatment was 5 days. The treated pots were taken into and out from the rooms at about 8 p.m. The following panicles of main culms and tillers were investigated: 1) the panicles which initiated flowering on the first day of the treatments, and 2) the panicles which initiated flowering on the day just before the treatments. The spikelets which flowered before the treatments were marked with an oleaginous fet pen. The number of panicles per plant was about 5 for all the lines.

All of the experiments in this study with the exception of that in 1984 were conducted in the college of Agriculture and Veterinary Medicine, Nihon University, Tokyo. In 1985, twelve seeds were sown along the brim of a $1 / 10,000$ a cylindrical pot which was manured with a chemical fertilizer at a level of $0.14 \mathrm{~g}$ for $\mathrm{N}, \mathrm{P}_{2} \mathrm{O}_{5}$ and $\mathrm{K}_{2} \mathrm{O}$ each. The lines were grown in natural light growth cabinets from June to September, which were set at $26^{\circ} \mathrm{C}$ (5 a.m. to 6 p.m.) and $20^{\circ} \mathrm{C}\left(6\right.$ p.m. to 5 a.m.). A high temperature treatment at $35^{\circ} \mathrm{C}$ from 9 a.m. to 5 p.m. for 5 days was conducted with a natural light growth cabinet in which 
the average relative humidity was $77 \%$. The panicles of the main culms, which initiated flowering on the first day of the treatment, were investigated. One to 5 spikelets per panicle which flowered after the treatment were observed on some of the panicles, and were marked with an oleaginous felt pen. On the first, third and fifth days during the treatment, about 40 spikelets per line were sampled after 6 p.m. and stored in a paper bag. The pistil in a spikelet was picked out, and was set on a slideglass. Pollen grains on stigmas were stained with cotton blue, and the number of pollen grains adhering on stigma hairs were counted under a microscope $(\times 400)$. The following pollen grains were judged to be germinated: 1) a pollen tube was shown on a pollen grain, 2) an empty pollen grain because its content seemed to go out due to the elongation of its pollen tube, and 3) more than half of the content of a pollen grain seemed to go out (see Fig. 1). It was frequent that no pollen tube was shown in the cases of 2) and 3).

\section{Experiments by the isogenic line of Taichung 65}

The other isogenic line of $d-47(\mathrm{t})$ was developed by the backcross of Tichung 65 . The donor of $d-47(\mathrm{t})$ was Taichung Native 1 . The number of backcrosses was 7 . Taichung 65 is a Japonica type cultivar developed in Taiwan before the Second World War. This line is designated as $d-47$ (T65) line in this paper. Its morphological and floral characteristics were reported by Murai et al. (1991).

In 1986, 12 seeds were sown along the brim of each $1 / 10,000$ a cylindrical pot which was fertilized at a level of $0.53 \mathrm{~g}$ for $\mathrm{N}, \mathrm{K}_{2} \mathrm{O}_{5}$, and $\mathrm{P}_{2} \mathrm{O}_{5}$ each. A slow-release coated fertilizer, $15 \%$ of each element of which is readily available, was used. It was presented by MITSUITOATSU-FERTILIZERS, INC. They were grown in natural light growth cabinets which were set at $25^{\circ} \mathrm{C}$ (5 a.m. to 6 p.m.) and $19^{\circ} \mathrm{C}(6$ p.m. to 5 a.m.), from May to October. A high

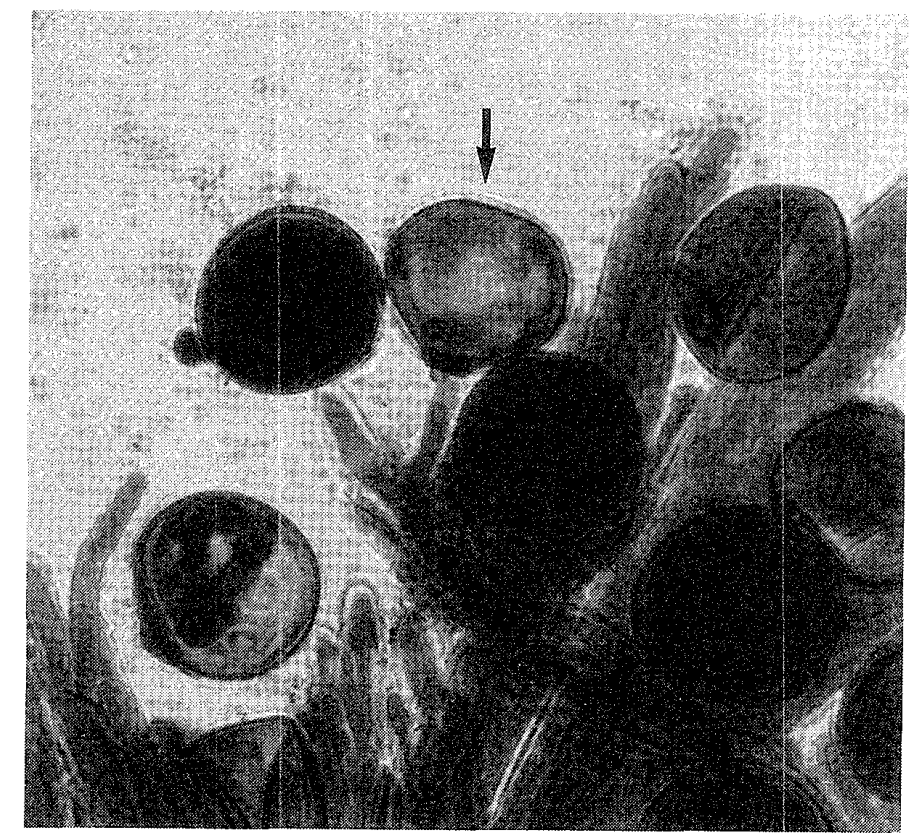

Fig. 1. A pollen grain, more than half of the content of which went out, in consequence of the elongation of its pollen tube (indicated by an arrow). 
temperature treatment at $35^{\circ} \mathrm{C}$ from 9 a.m. to 5 p.m. for 4 days was conducted with a natural light growth cabinet in which the average relative humidity at $35^{\circ} \mathrm{C}$ was $78 \%$.

In 1987, 8 seeds were sown along the brim of each $1 / 10,000$ a cylindrical pot which was manured at a level of $0.49 \mathrm{~g}$ for $\mathrm{N}, \dot{\mathrm{K}}_{2} \mathrm{O}$ and $\mathrm{P}_{2} \mathrm{O}_{5}$ each. Another slow-release coated fertilizer, only $5 \%$ of each element of which is readily available, was used. They were grown in natural light growth cabinets of the same temperature setting as in 1986. A high temperature treatment at $37^{\circ} \mathrm{C}$ from 9 a.m. to 5 p.m. for 3 days was conducted in an artificial light growth room which was illuminated at about $20,000 \mathrm{~lx}$ from 5 a.m. to 8 a.m. and at about $60,000 \mathrm{~lx}$ from 8 a.m. to $6 \mathrm{p} . \mathrm{m}$. The relative humidity at $37^{\circ} \mathrm{C}$ was kept at about $77 \%$. During the treatment, a pot of another type was set under each pot of $d-47$ (T65) line, and the positions of its panicles were raised up to those of Taichung 65 .

In both years, the panicles of the main culms, which initiated flowering on the first day of the treatment and on the day just before the treatments, were investigated. The spikelets which flowered before and after the treatments were marked with black and red oleaginous felt pens, and were not involved in calculating the spikelet fertility of each panicle. On each day during the treatments, 40 50 spikelets per line were sampled after 6 p.m. and stored in a paper bag. Pollen grains were investigated in the same manner as in 1985.

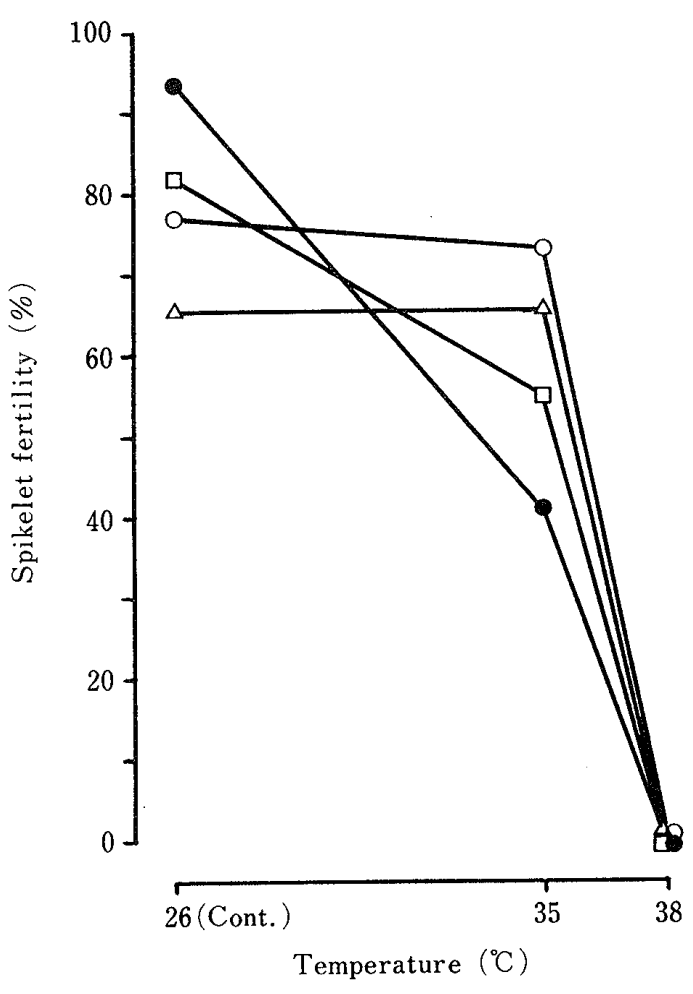

(1) Panicles which initiated flowering on the first day of the treatments.

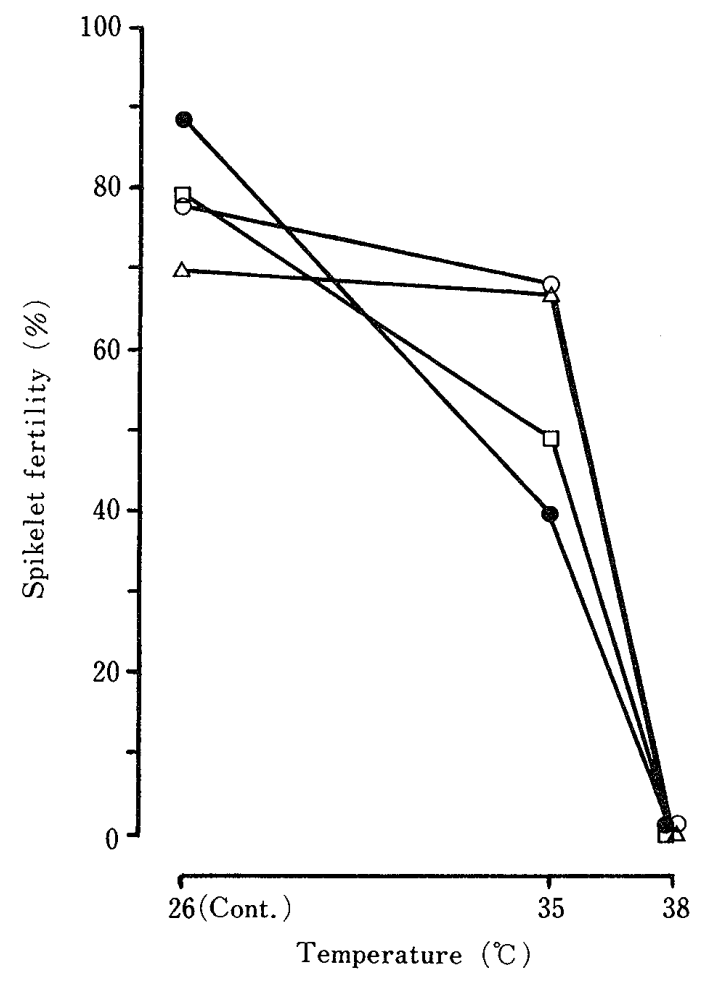

(2) Panicles which initiated flowering on the day just before the treatments.

Fig. 2. Reactions of Shiokari and its isogenic lines to high temperature in spikelet fertility in 1984 .

$\square \cdot d-12$ line.

$\triangle \mathrm{d}-18^{\mathrm{k}}$ line.

d-47 line.

- Shiokari. 


\section{Results}

\section{Experiments by isogenic lines of Shiokari}

Fig. 2 shows the reactions of Shiokari and its isogenic lines to high temperature in spikelet fertility in 1984 . Shiokari showed the steepest decrease (about $50 \%$ ) from $26^{\circ} \mathrm{C}$ to $35^{\circ} \mathrm{C}$, followed by $d-12$ line. On the other hand, $d-18^{k}$ line and $d-47$ line showed small or no decrease from $26^{\circ} \mathrm{C}$ to $35^{\circ} \mathrm{C}$. At $38^{\circ} \mathrm{C}$, almost all the spikelets were sterile in all the lines. In 1985 , Shiokari showed a low spikelet fertility at $35^{\circ} \mathrm{C}$ similar to those in 1984 , while $d-18^{k}$ line, $d-47$ line and $d-12$ line showed higher spikelet fertilities (Fig. 3). The spikelet fertility of $d-35$ line was lower than that of Shiokari. Fig. 4 shows a relation between the spikelet fertility in this study and the percentage of fertilized spikelets discerned by "iodine reaction of starch (MATSUSHIMA and TANAKA 1960)." In the former, it was tested by touching with fingers whether there was any endosperm in a spikelet or not. By using the latter method, the spikelets, the pistils of which stopped development as early as one day after fertilization, can be discerned from non-fertilized spikelets. Values in the former and latter almost agreed in all the lines both in the $35^{\circ} \mathrm{C}$ treatment and the control. Fig. 5 shows the

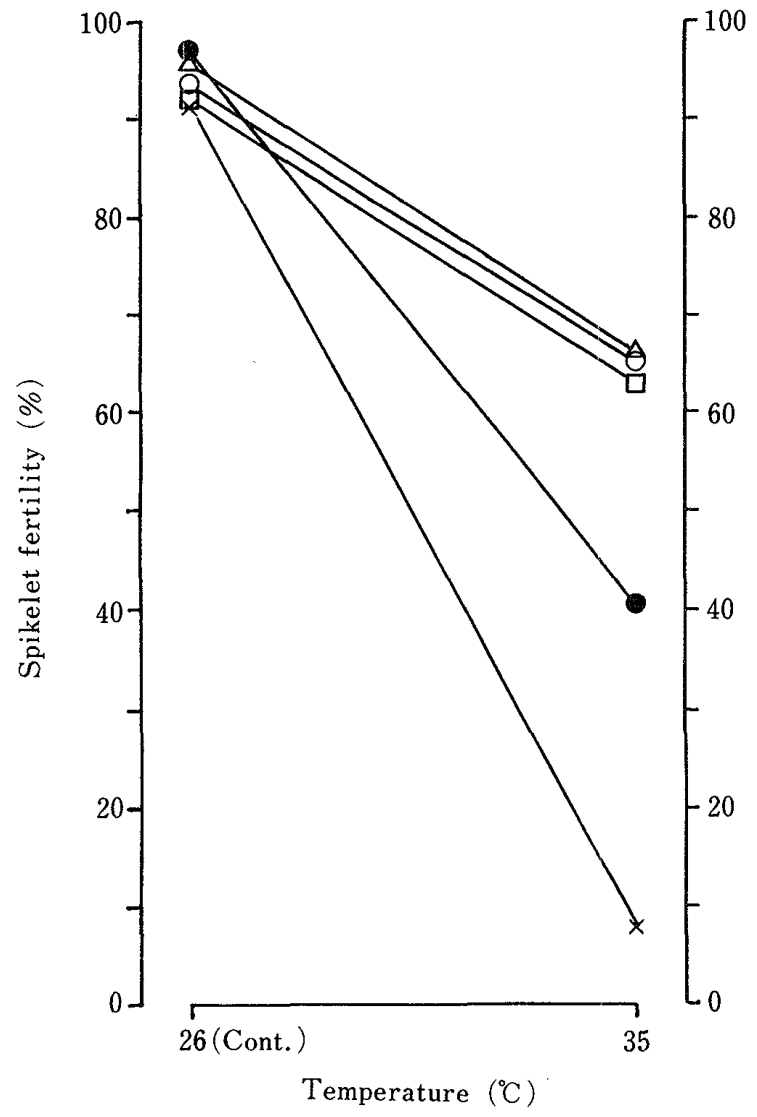

Fig. 3. Reactions of Shiokari and its isogenic lines to high temperature in spikelet fertility in 1985 .

$\square \mathrm{d}-12$ line.

$\triangle \mathrm{d}-18^{\mathrm{k}}$ line.

$\times d-35$ line.

d-47 line.

- Shiokari.

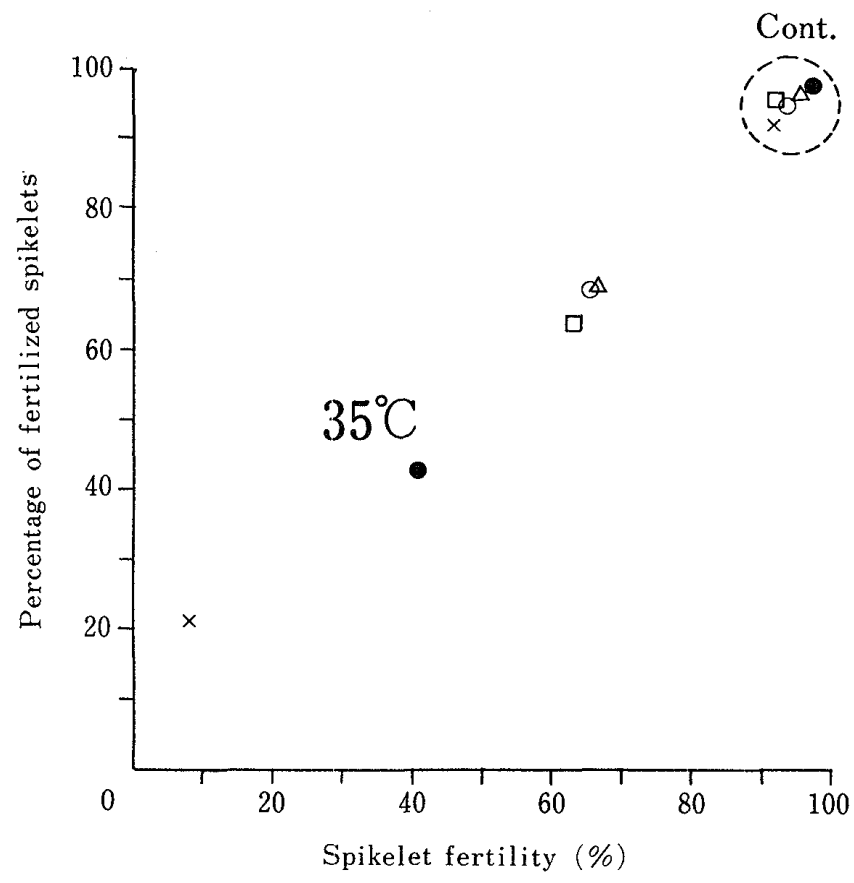

Fig. 4. Relation between the spikelet fertility and the percentage of fertilized spikelets discerned by the iodine reaction of starch.

Symbols are the same as in Fig. 3. 
number of pollen grains adhered on stigma hairs per spikelet, which was divided into 0 (no pollen grain), $1 \sim 9,10 \sim 19,20 \sim 29$, and more than 29 , and the proportion of spikelets belonging to each group was exhibited by the percentage to the total number of spikelets. In

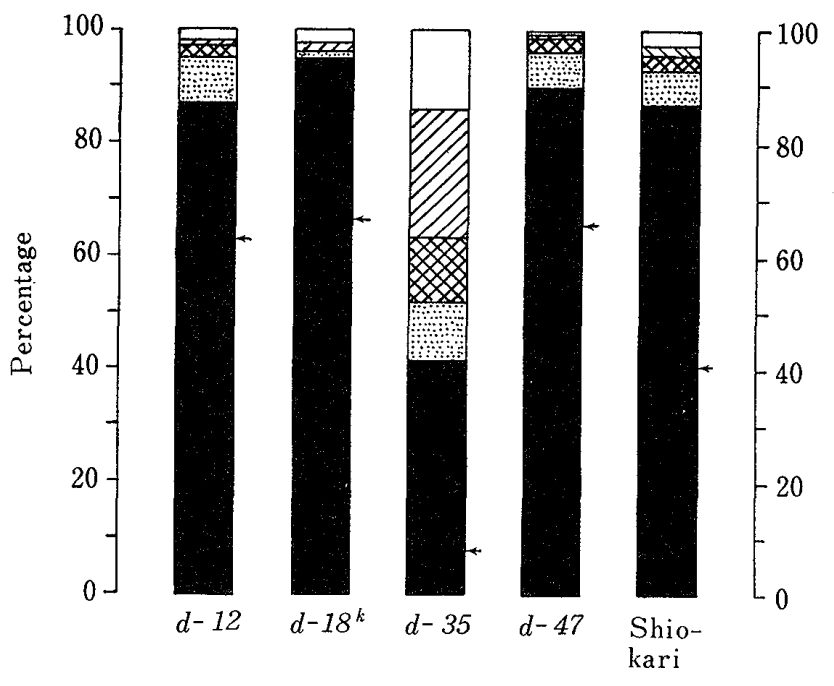

(1) $35^{\circ} \mathrm{C}$.

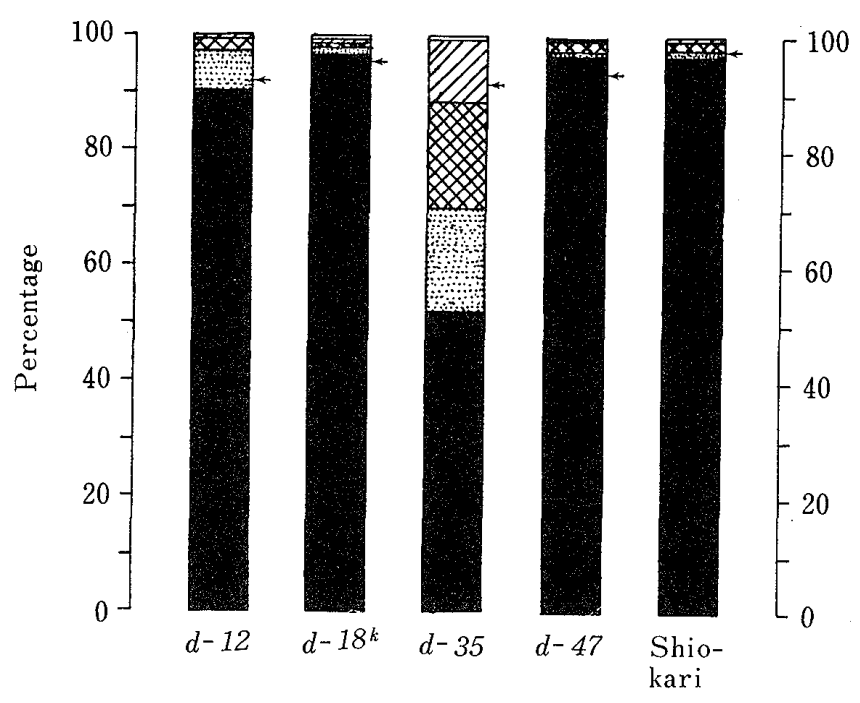

(2) Control.

Fig. 5. The number of pollen grains adhered on stigma hairs per spikelet in Shiokari and its isogenic lines in 1985.

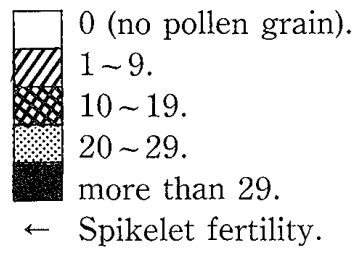

the percentage of more than 29 pollen grains at $35^{\circ} \mathrm{C}, d-35$ line showed a value distinctly lower than the other lines. In addition, there was $13.9 \%$ of no pollen grain. These seem to result in the low spikelet fertility of $d-35$ line at $35^{\circ} \mathrm{C}$. Further, $d-35$ line showed distinctly fewer pollen grains per spikelet in the control than the other lines. On the other hand, $d-18^{k}$ line showed the highest percentage of more than 29 pollen grains at $35^{\circ} \mathrm{C}$ as well as the highest spikelet fertility at $35^{\circ} \mathrm{C}$. As shown in Fig. 6, the percentage of more than 29 pollen grains at $35^{\circ} \mathrm{C}$ was significantly correlated with the spikelet fertility at $35^{\circ} \mathrm{C}$. Fig. 7 shows the number of germinated pollen grains per spikelet, which was divided into 0 (no germinated pollen grain), $1 \sim 9, \quad 10 \sim 19$, and more than 19, and the proportion of

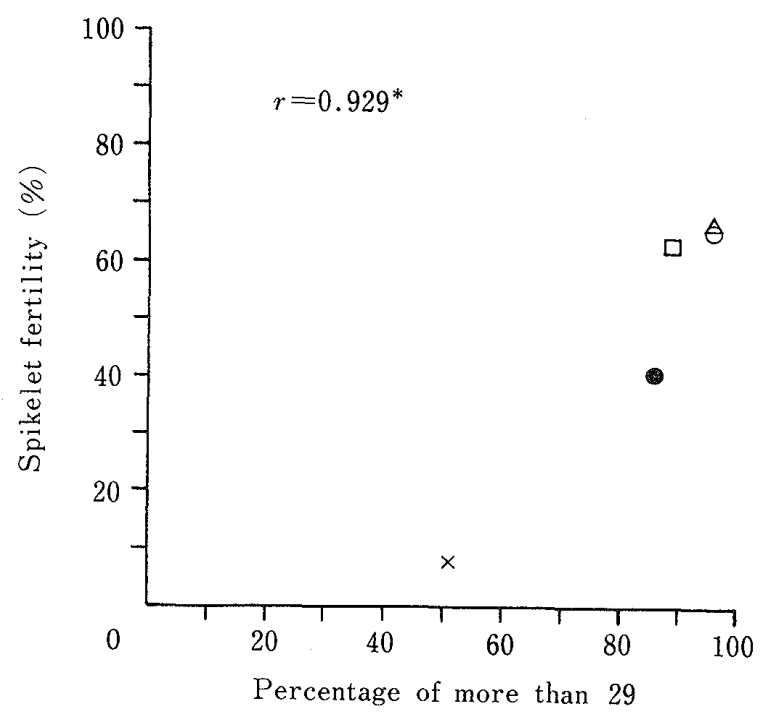

Fig. 6. Correlation between the spikelet fertility and the percentage of spikelets with more than 29 pollen grains on stigma hairs at $35^{\circ} \mathrm{C}$ in 1985 .

*Significant at 0.05 level.

Symbols are the same as in Fig. 3 . 
spikelets belonging to each group was exhibited by the percentage to the total number of spikelets. $d-35$ line showed distinctly fewer germinated pollen grains per spikelet at $35^{\circ} \mathrm{C}$ than the other lines. There was $22.3 \%$ of no germinated pollen grain at $35^{\circ} \mathrm{C}$. In the percentage of more than 19 at $35^{\circ} \mathrm{C}$, the lines were in the other of $d-18^{k}$ line $>d-47$ line $>d-12$ line $>$ Shiokari $>d-35$ line. Fig. 8 shows the correlation between the spikelet fertility and the

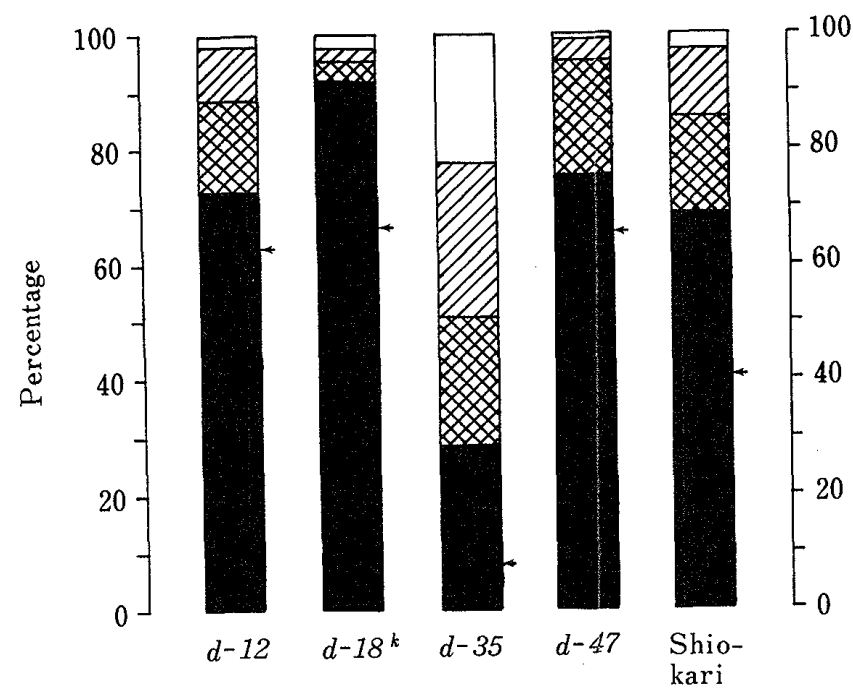

(1) $35^{\circ} \mathrm{C}$.

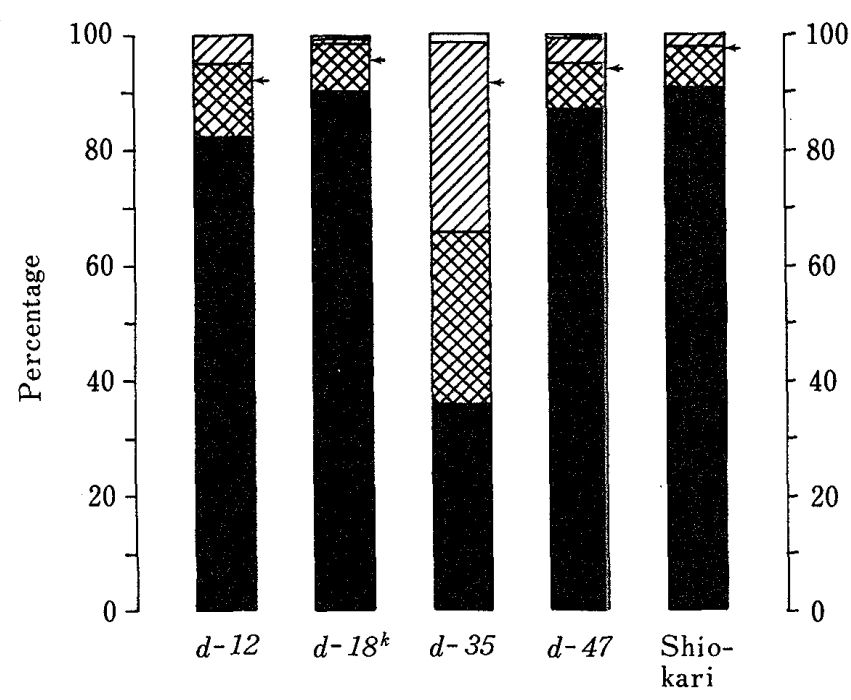

(2) Control.

Fig. 7. The number of germinated pollen grains per spikelet in Shiokari and its isogenic lines in 1985.

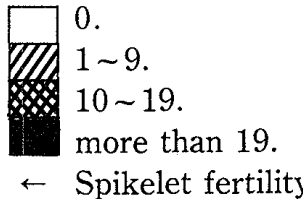

percentage of more than 9 or 19 germinated pollen grains at $35^{\circ} \mathrm{C}$. The spikelet fertility was highly significantly correlated with the percentages, indicating that the more the germinated pollen grains the higher the spikelet fertility at $35^{\circ} \mathrm{C}$.

\section{Experiments by the isogenic line of Taichung 65}

Table 1 shows the spikelet fertilities at $35^{\circ} \mathrm{C}$ and $37^{\circ} \mathrm{C}$ in 1986 and 1987 , respectively, and those in the controls. Both of $d-47$ (T65) line and Taichung 65 showed little decrease of spikelet fertility at $35^{\circ} \mathrm{C}$. At $37^{\circ} \mathrm{C}$, Taichung 65 had almost no fertile spikelet, but $d-47$ (T65) line had some fertile spikelets $(8.8 \%)$ ). Fig. 9 shows the number of pollen grains adhered on stigma hairs per spikelet. Both lines showed little decrease at $35^{\circ} \mathrm{C}$ in the number. A similar result was shown in the number of germinated pollen grains per spikelet (Fig. 10-(1)). At $37^{\circ} \mathrm{C}$, on the other hand, the percentages of no pollen grain were $76.9 \%$ of Taichung 65 and $37.0 \%$ of $d-47$ (T65) line (Fig. 9-(2)). Table 2 shows the percentage of pollen germination: the percentage was calculated for the spikelets, the number of adhered pollen grains of which were from 2 to 99 . Both lines showed no decrease at $35^{\circ} \mathrm{C}$ in the percentage. At $37^{\circ} \mathrm{C}$, on the other hand, the percentages of both lines were remarkably low.

\section{Discussion}

SATAKe and Yoshida (1978) conducted several experiments on the high temperature damage at flowring. One of those 
Table 1. The Spikelet fertilities (\%) of $d-47$ (T65) line and Taichung 65 at $35^{\circ} \mathrm{C}$ and $37^{\circ} \mathrm{C}$, and in the controls

\begin{tabular}{lcccccc}
\hline \multirow{2}{*}{ Line } & \multicolumn{2}{c}{1886} & & \multicolumn{2}{c}{1987} \\
\cline { 2 - 3 } \cline { 6 - 7 } & $35^{\circ} \mathrm{C}$ & Cont. & & $37^{\circ} \mathrm{C}$ & Cont. \\
\hline d-47(T65) line & 94.0 & 95.5 & & 8.8 & 97.7 \\
Taichung 65 & 93.1 & 96.4 & & 0.4 & 97.9 \\
\hline
\end{tabular}

Table 2. The percentage of pollen germination of $d-47$ (T65) line and Taichung 65 at $35^{\circ} \mathrm{C}$ and $37^{\circ} \mathrm{C}$, and in the controls

\begin{tabular}{lcccccc}
\hline \multirow{2}{*}{ Line } & \multicolumn{2}{c}{1886} & & \multicolumn{2}{c}{1987} \\
\cline { 2 - 3 } \cline { 6 - 7 } \cline { 5 - 6 } & $35^{\circ} \mathrm{C}$ & Cont. & & $37^{\circ} \mathrm{C}$ & Cont. \\
\hline Taichung 65 65 & 83.0 & 77.6 & & 25.9 & 81.1 \\
\hline
\end{tabular}

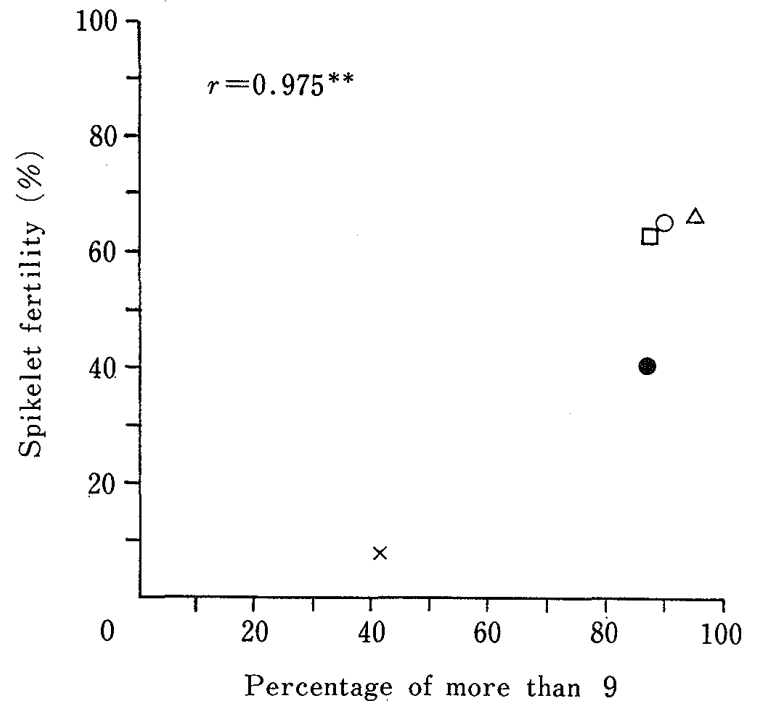

(1) More than 9.

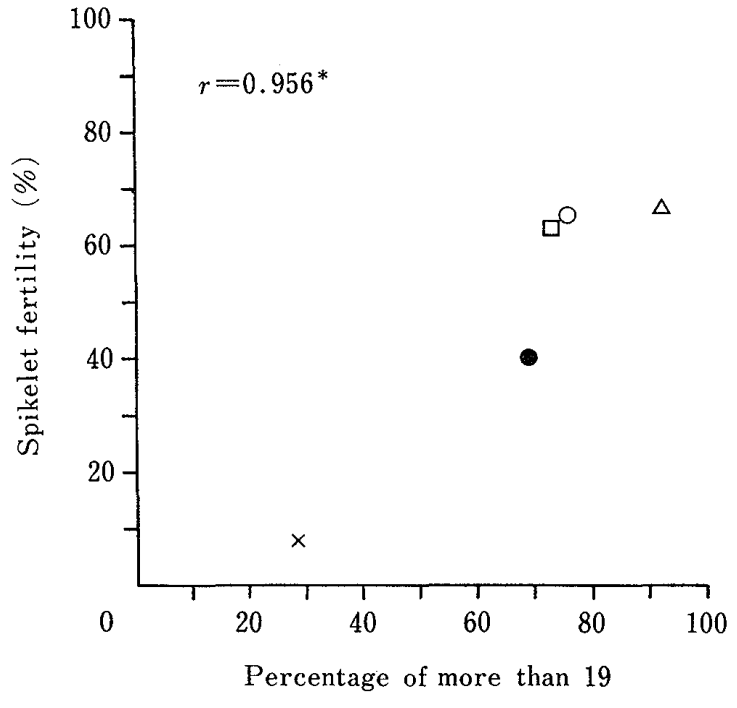

(2) More than 19.

Fig. 8. Correlation between the spikelet fertility and the percentage of spikelets with more than 9 or 19 germinated pollen agrains at $35^{\circ} \mathrm{C}$ in 1985 .

*, **Significant at 0.05 and 0.01 levels, respectively. Symbols are the same as in Fig. 3.

showed that the spikelet fertilities of susceptible, moderate and tolerant varieties were about 10,80 and $90 \%$, respectively, at $35^{\circ} \mathrm{C}$, and those of the former two at $38^{\circ} \mathrm{C}$ were near to $0 \%$. At $35^{\circ} \mathrm{C}$ in 1985 in this study, the spikelet fertility of Shiokari was $40.5 \%$, indicating that its tolerance is between the susceptible and the moderate. Those of $d-35$ line, $d-12$ line, $d-47$ line and $d-18^{k}$ line were $8.1,62.9,65.3$ and $66.3 \%$, respectively. In $1984, d-12$ line showed the lower fertility at $35^{\circ} \mathrm{C}$ than $d-47$ line. Accordingly, it is inferred that $d-47(\mathrm{t})$ and $d-18^{k}$ followed by $d-12$ enhance the high temperature tolerance but $d-35(\mathrm{t})$ lowers it. Further, $d-47(\mathrm{~T} 65)$ line had some fertile spikelets at $37^{\circ} \mathrm{C}$, while Taichung 65 had almost no 


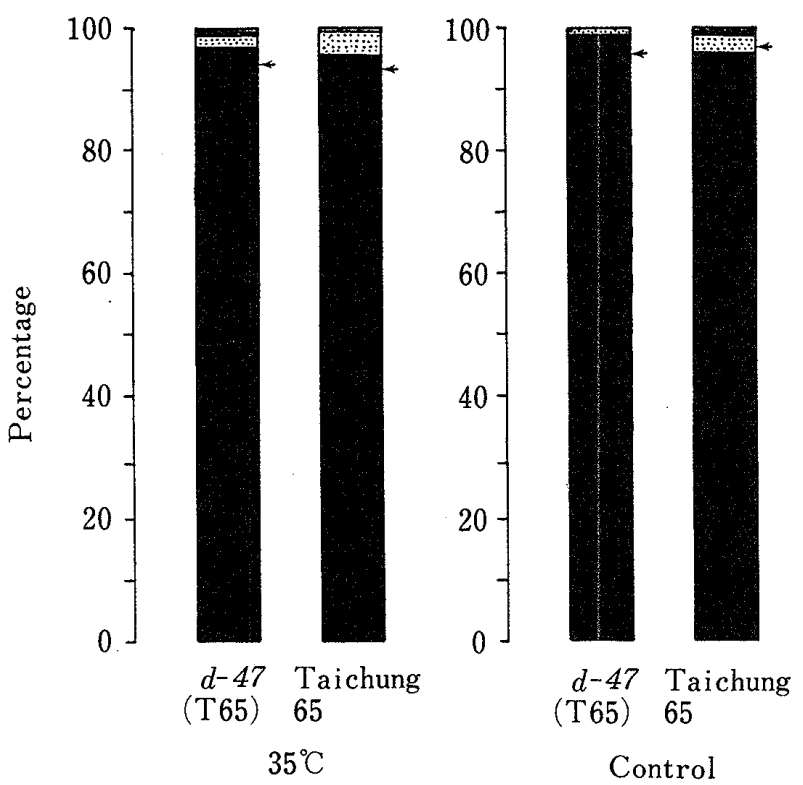

(1) 1986 .

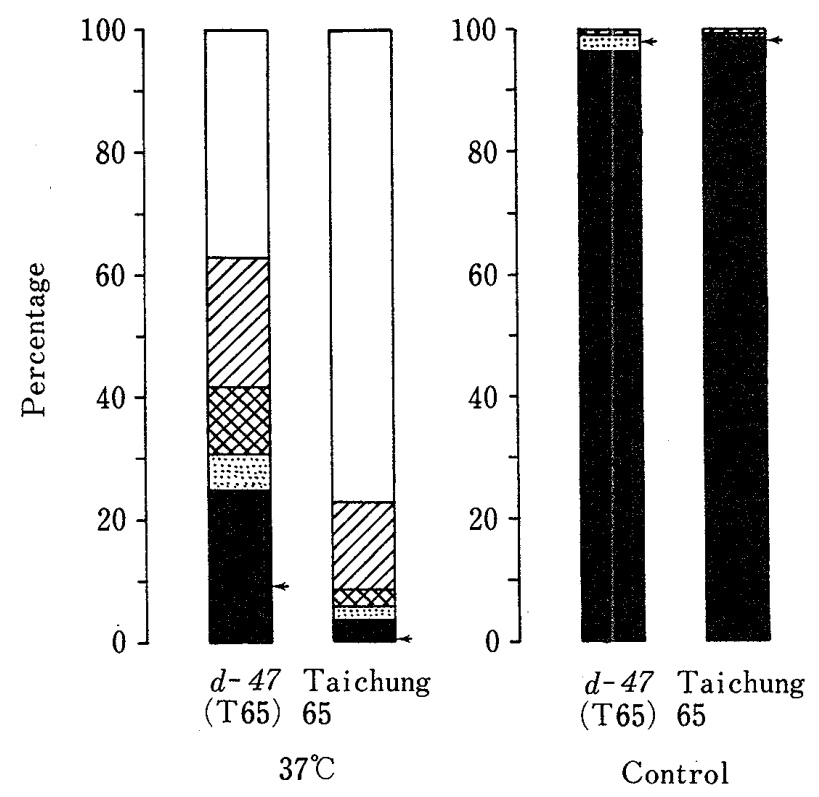

(2) 1987 .

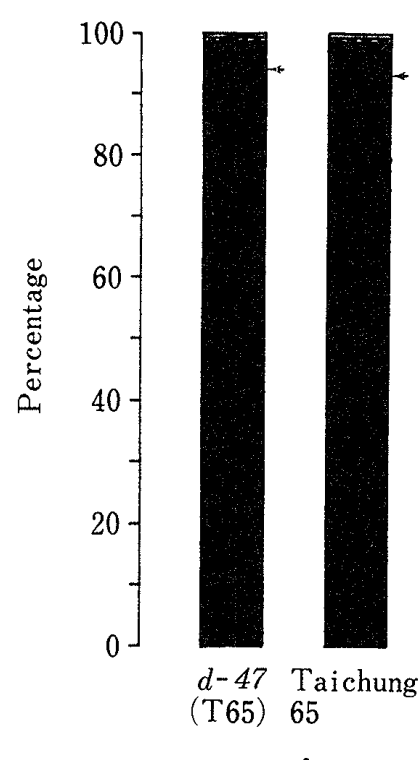

$35^{\circ} \mathrm{C}$

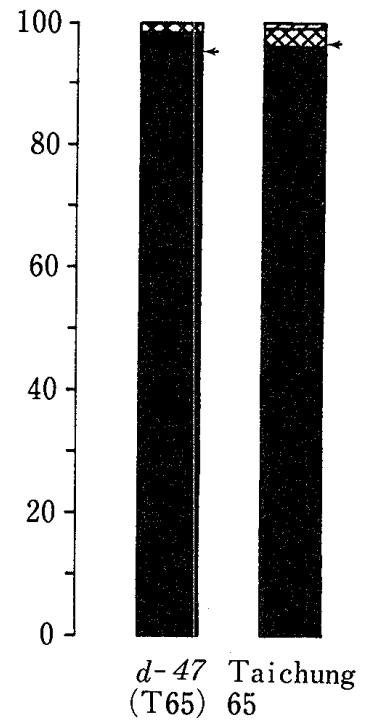

Control

(1) 1986 .
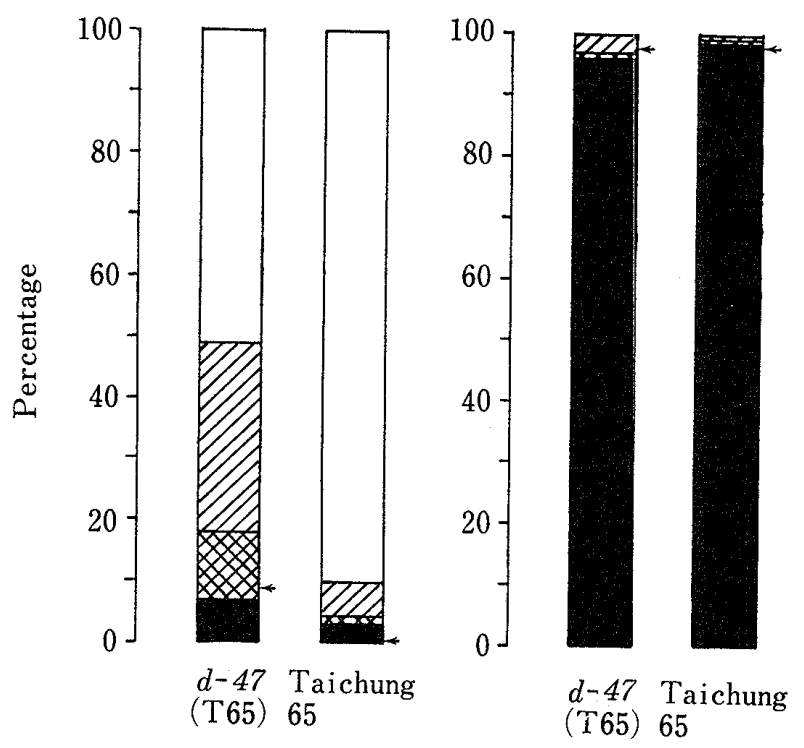

Control

(2) 1987 .

Fig. 9. The number of pollen grains adhered on stigma hairs per spikelet in $d-47$ (T65) line and Taichung 65.

0 (no pollen grain).
$1 \sim 9$.
$10 \sim 19$.
$20 \sim 29$.
more than 29.

Fig. 10. The number of germinated pollen grains per spikelet in $d-47$ (T65) line and Taichung 65.

$$
\begin{aligned}
& 0 . \\
& 1 \sim 9 . \\
& 10 \sim 19 . \\
& \text { more than } 29 . \\
& \leftarrow \text { Spikelet fertility. }
\end{aligned}
$$


fertile spikelet. Taichung 65 showed a fertility higher than $90 \%$ at $35^{\circ} \mathrm{C}$. Hence, the tolerance of Taichung 65 seems to correspond to the moderate tolerance by SATAKE and YoshrDA (1978). Thus, it is recognized that $d-47(\mathrm{t})$ enhanced the high temperature tolerance under the two genetic backgrounds with different tolerances. However, the following possibility can not be completely denied: a gene which enhances the high emperature tolerance is closely linked with $d-47(\mathrm{t})$ on the same chromosome.

The study of Satake and Yoshida (1978) indicated that the percentage of spikelets with more than 9 germinated pollen grains was almost identical with the spikelet fertility on the temperature range from 29 to $38^{\circ} \mathrm{C}$; i.e., 10 germinated pollen grains were necessary for fertilization. A similar result was obtained by Togari and Kashiwakura (1958). It mostly applies to the results of the lines in the controls (Fig. 7 and 10 ). At $35^{\circ} \mathrm{C}$ in 1985 , however, the spikelet fertility was apparently lower than the percentage of spikelets with more than 9 germinated pollen grains in each of the lines (Fig. 7), indicating that far more than 9 germinated pollen grains per spikelet were needed for fertilization. YAmADA et al. (1955) observed that the full length of a pollen tube was reduced on the temperature range from 30 to $40^{\circ} \mathrm{C}$. Therefore, there is a possibility that the elongation of a pollen tube after germination was depressed at $35^{\circ} \mathrm{C}$ in Shiokari and its isogenic lines, increasing non-fertilization.

SATAKe and Yoshida (1978) found under high temperature conditions that anthers of the tolerant variety easily dehisced resulting in many pollen grains on a stigma; on the other hand, many anthers of the susceptible variety did not dehisce resulting in no pollen grain on a stigma. In this study, the trend was shown among Shiokari and its isogenic lines at $35^{\circ} \mathrm{C}$ that the more the pollen grains adhered per spikelet, the higher the spikelet fertility (Fig. 5 and 6). Further $d-47$ (T65) line had more pollen grains adhered per spikelet than Taichung 65 (Fig. 9). Therefore, it is inferred that $d-47(\mathrm{t})$ acts to somewhat facilitate anther dehiscence under high temperature conditions.

Murai et al. (1991) obtained results indicating that $d-47(\mathrm{t})$ lowers the cool temperature tolerance at the booting stage. Accordingly, it is considered that $d-47(\mathrm{t})$ originated from Deegeo-woo-gen is suited to the tropics rather than to cold climatic regions.

\section{Acknowledgement}

The authors wish to express deepest appreciation to Dr. I. Sato Professor Emeritus, Tottori University for making this study possible. They are grateful to Prof. T. Satake, Hokkaido Takusyoku Junior College for his valuable advice, and to Mr. Y. SATo, Mr. N. Koyama and Mr. F. Tomikawa for their cooperation in carrying out the experiments.

\section{Literature Cited}

Futsuhara, Y. 1968. Breeding of a new rice variety Reimei by gamma-ray irradiation. Gamma Field Symp. $7: 87 \sim 109$. ter $3: 8 \sim 10$.

Hokkaido Central Agricultural Experiment Station 1979. (8) Shiokari. Misc. Pub. Hokkaido Prefect. Agric. Exp. Stn. 9:7 8. 
ITO, H. 1964. Rice cultivation in Iraq. Kokusai-shokuryo-nogyo (published by Japan FAO Association) 13(9) : $1 \sim 39$.

Japan Meterological Agency 1990. Monthly mean temperatures in the world. In "Rika nenpyo (Chronological Scientific Tables) 1991" National Astronomical Observatory of Japan (eds.), Maruzen Co., Ltd., Tokyo, $304 \sim 325$.

Kinoshita, T. and N. ShINBASH 1982. Identification of dwarf genes and their character expression in the isogenic background. Japan. J. Breed. $32: 219 \sim 231$.

Matsushima, S. and T. TanaKa 1960. Analysis of developmental factors determining yields and its application to yield prediction and culture improvement of lowland rice. LV. Early discrimination of non-fertilized rice-grain. Proc. Crop Sci. Soc. Japan 28:365 366.

Matsushima, S., H. Ikewada, A. Maeda, S. Honma and H. Niki 1982. Studies on rice cultivation in the tropics. 1. Yielding and ripening responses of the rice plant to the extremely hot and dry climate in Sudan. Japan. J. Trop. Agr. 26:19 25.

Murai, M., N. Shinbashi and T. Kinoshita 1982. Classification of nineteen kinds of near-isogenic dwarf lines due to the characters of internodes. Genetical studies on rice plant SXXXIV. J. Fac. Agr. Hokkaido Univ. 61:73 90.

and KINOSHITA 1983. Pleiotropic effects of dwarf genes for panicle and grain characters. Genetical studies on rice plant, LXXXVI. Res. Bull. Univ. Farm Hokkaido Univ. 23:1 10.

- N. Shinbashi, A. Kusutani, S. Hirose, I. Takamure and $\mathbb{T}$. Kinoshita 1990. Identification of dwarf genes in rice lines, Yukara dwarf and Fukei 71, and its response to environmental factors. Japan. J. Breed. $\mathbf{4 0}: 33 \sim 45$.

- S. Hirose, S. SATo and M. TAKeBE 1991. Effects of dwarfing genes from Dee-geo-woo-gen and other varieties on cool temperature tolerance at booting stage in rice. Japan. J. Breed. 41(2) : $241 \sim 254$.

Nishiyama, I. and T. Satake 1981. High temperature damages in rice plants. Japan. J. Trop. Agr. $25: 14 \sim 19$.

Okada, M., Y. Yamakawa, K. FujiI, H. Nishiyama, H. Kimura, S. Kai and T. Imai 1967. On the new varieties of paddy rice, "Hoyoku, Kokumasari and Shiranui". Bull. Kyushyu Agr. Exp. Sta. $12: 187 \sim 224$.

Osada, A., V. Sasiprapa, M. Rahong, S. Dhammanuvong and H. Chakrabandhu 1973. Abnormal occurrence of empty grains of indica rice plants in the dry, hot season in Tailand. Proc. Crop Sci. Soc. Japan $42: 103 \sim 109$.

SATAKE, T. and S. YoshIDA 1978. High temperature-induced sterility in indica rices at flowring. Japan Jour. Crop Sci. $47: 6 \sim 17$.

SATO, I 1982. Rice cultivation and water management in arid lands. -Examples on oases in EgyptSogonogyosuiri-oyobi-tansuikoka $6: 8 \sim 18$.

Togari, Y. and Y. KashiwakuRA 1958. Studies on the Sterility in rice plant induced by superabundant nitrogen supply and insufficient light intensity. Proc. Crop Sci. Soc. Japan 27:3 5.

UCHIYAMADA, H. 1981. Possibility of breeding superhigh yielding rice cultivas for feed. Ikushugakusaikinnoshinpo (edited by Japanese Society of Breeding) $22: 20 \sim 52$.

Yamada, I., K. Hozumi and C. Enomono 1955. On the artificial germination of pollen in rice plants (III) Temperature relations of pollen germination and pollen tube growth. Proc. Crop Sci. Soc. Japan 23: 321 . 


\author{
イネにおける低脚烏尖由来の矮性遺伝子ならびに他の3種の矮性遺伝子が \\ 開花期の高温耐性に及ぼす作用 \\ 村井正之 $之^{1)}$ - 広瀬昌平 ${ }^{1)}$ ・鈴木則行 ${ }^{1)}$ ・ \\ 山根正勝 ${ }^{2} \cdot$ 佐藤茂俊 ${ }^{3}$

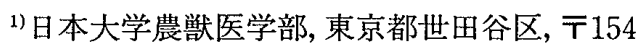 \\ 2)鳥取大学乾燥地研究センター, 鳥取市, $\overline{\mathrm{T}} 680$ \\ 3)琉球大学農学部, 沖縄県西原町, $7903-01$
}

$d-47$ ( $\mathrm{t})$ (低脚鳥尖矮性),$d-12$ (ユーカラ矮性),$d-18^{\mathrm{k}}$ (小丈玉錦矮性) および $d-35$ ( $\mathrm{t}$ ) (短銀坊主矮性) が開花 期の高温耐性に作用を及ぼすか否かを調べた。

供試系統としては, しおかりを反復親とした同質遺伝子系統である $d-47$ 系統， $d-12$ 系統， $d-18^{\mathrm{k}}$ 系統および $d$ -35 系統,ならびに, 台中 65 号を反復親とした同質遺伝子系統である $d-47$ (T65) 柔統を用いた.

1984年には, $35^{\circ} \mathrm{C}$ なびに $38^{\circ} \mathrm{C}$ 処理を 5 日間行った. 1985 年ならびに 1986 年には, $35^{\circ} \mathrm{C}$ 処理を 5 日間ならびに 4 日間行っ た. 1987 年には, $37^{\circ} \mathrm{C}$ 処理を 3 日間行った. 処理時間は, 1984 年が午前 9 時から午後 6 時の 9 時間であった以外は,いずれも 午前9時から午後5時までの8時間であった.これらの処理は, 自然光もしくは人工光の人工気象室にて行った.

1984年の $35^{\circ} \mathrm{C}$ 処理では, 各系統の稳実歩合は, $d-47$ 系統> $d-18^{\mathrm{k}}$ 系統 $>d-12$ 系統>しおかり,の順であった (Fig.

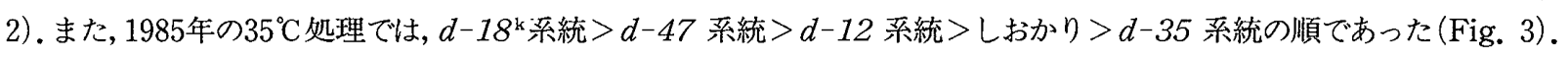
故に, $d-47(\mathrm{t})$ と $d-18^{\mathrm{k}}$ および $d-12$ は開花期の高温に対する耐性を高める作用を有し, 反对に $d-35(\mathrm{t})$ は低下さ

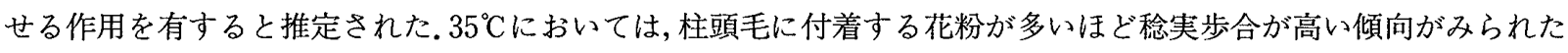
(Fig. 5および6).また, 発芽花粉数においても同様の傾向がみられた（Fig. 7および8).

台中 65 号と $d-47$ ( T 65) 系統は, $35^{\circ} \mathrm{C}$ におて $70 \%$ 以上の稔奉歩合を示し, 柱頭上の花粉数や発芽花粉数も減少し

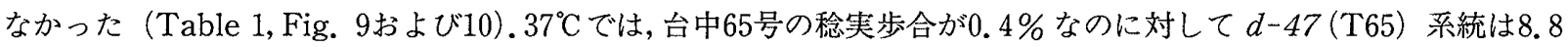
\%あった (Table 1).そのとき, 台中65号と $d-47$ (T65) 系統において, 柱頭毛に花粉の全くない穎花の割合は, それ ぞれ76.9\%と37.0\%であった (Fig. 9). さらに, 両柔統とも花粉発芽率の著しい減少がみられた（Table 2).

以上より， $d-47(\mathrm{t})$ は, 異なった遺伝的背景のもとで開花期の高温耐性を向上させたことが認められた.また, 本実 験に扔ける耐性の差異は, 高温時に䒺が裂開しやすいいか否かに起因すると推定された。 